Proc. Indian Acad. Sci. (Earth Planet. Sci.), Vol. 95, No. 3, November 1986, pp. 417-426.

(C) Printed in India.

\title{
Estimation of evaporation rates over the Arabian Sea from satellite data
}

\author{
$M$ VENKATESWARA RAO*, V RAMESH BABU, \\ L V GANGADHARA RAO and J S SASTRY \\ National Institute of Oceanography, Donapaula, Goa 403004 India \\ * National Remote Sensing Agency, Secunderabad 500 037 India \\ MS received 7 February 1986; revised 24 June 1986
}

\begin{abstract}
Utilizing both the SAMIR brightness temperatures of Bhaskara II and GOSSTCOMP charts of NOAA satellite series, the evaporation rates over the Arabian Sea for June 1982 are estimated through the bulk aerodynamic method. The spatial distribution of evaporation rates estimated from the satellite data sets coincides well with those obtained from ship observations as well as from climatological data. The accuracy in the estimation of evaporation rates has considerably been improved after the removal of bias in sea surface temperature and is about $\pm 0.8 \mathrm{~mm} / \mathrm{day}$.
\end{abstract}

Keywords. Satellite microwave radiometer; Bhaskara II; evaporation; GOSSTCOMP charts; air-sea exchange.

\section{Introduction}

The ocean-atmospheric coupled system exchanges heat, momentum and energy between the two fluids. A larger part of the heat is supplied by the tropical oceans, through evaporation for development of large-scale weather systems. Monsoon rainfall pattern over India has been related to the air-sea interaction parameters over the Arabian Sea (Shukla 1975; Shukla and Mishra 1977; Bhumralkar 1978; Rao et al 1981; Gadgil et al 1984 and Babu et al 1985). The knowledge of evaporation rates over the ocean is essential for parametrizing ocean-atmospheric coupled predictive models. For real-time acquisition of evaporation fields over wider oceanic areas, Liu (1984) suggested the possibility of using satellite measurements of surface wind speed (SW), sea surface temperature (SST) and integrated water vapour (WV) content data derived from satellite multichannel microwave radiometer (SMMR) in the bulk parametrization method in which the WV content was related with surface humidity. He further suggested the possibility of combining observations from different sensors such as infrared sensors AVHRR (advanced very high resolution radiometer), HIRS (high resolution infrared sensor), VAS (VISSR atmospheric sounder) and microwave radiometers on board individual satellites for the estimation of evaporation rates. Taylor (1984) also mentioned that satellite microwave radiometers provide good estimates of parameters for use with the bulk aerodynamic formula. Several investigations have been reported in the literature relating WV content in the atmosphere with humidity fields in the lower levels over different regions (Reitan 1963; Bolsenga 1965; Smith 1966 and Zillman 1972). Similar studies have not been documented so far over the northern Indian Ocean. 
In the present paper, the feasibility of deriving evaporation rates from SAMIR data of Indian satellite Bhaskara-II and AVHRR data of NOAA series is studied. An empirical relation between surface dew point temperature and WV content is derived for monsoon season based on observations made over both the Arabian Sea and the Bay of Bengal where seasonal variability of weather is well pronounced. A typical mean monthly distribution (June 1982) of evaporation rate over the Arabian Sea estimated from satellite data is compared with that obtained from ship's data and also with climatological pattern.

\section{Data and methods}

The evaporation rate $E(\mathrm{~cm} / \mathrm{day})$ from the sea surface can be estimated from the following bulk-aerodynamic formula

$$
E=9.0284 \times 10^{-3}\left(e_{s}-e_{a}\right) U_{a},
$$

where $e_{s}$ and $e_{a}$ are the saturated vapour pressure of air $(\mathrm{mb})$ at SST and vapour pressure of air $(\mathrm{mb})$ at anemometer height respectively and $U_{a}$ is the wind speed $(\mathrm{m} / \mathrm{sec})$ at anemometer level. The constant $\left(9 \cdot 0284 \times 10^{-3}\right)$ has been obtained after considering $\rho$ (density of air) as $1.2 \times 10^{-3}\left(\mathrm{~g} / \mathrm{cm}^{3}\right)$ and $C_{D}$ (drug coefficient) as $1.4 \times 10^{-3}$ (Rao et al 1981) though $C_{D}$ varies with wind speed and low level stability. The assumption of constant $\rho$ and $C_{D}$, if applied uniformly in both sources of data (satellite and ship), may not matter as far as relative comparison of results from these two sources is concerned.

SAMIR (satellite microwave radiometer) data analyzed for this study are limited to $4^{\circ}$ to $24^{\circ} \mathrm{N}$ and $60^{\circ}$ to $80^{\circ} \mathrm{E}$ over the Arabian Sea. The values of surface dew point temperature and wind speeds derived from SAMIR and SST from AVHRR (NOAA) averaged over each $4^{\circ}$ square grid in the study area of the Arabian Sea during June 1982 have been used in (1). In the analysis of evaporation rates derived from conventional ship's data obtained from Indian Daily Weather Reports (IDWRs), linear interpolation has been done for some grids for which data are not available.

\subsection{Retrieval of WV content and surface wind speeds from SAMIR}

The SAMIR on board Bhaskara II, an Indian experimental satellite for earth observations, consists of three Dicke type microwave radiometers which measure the brightness temperature at $31.4,19.35$ and $22.235 \mathrm{GHz}$ with a spatial resolution of $125 \mathrm{~km}$ and a temperature resolution of about $1{ }^{\circ} \mathrm{K}$. The details of SAMIR sensor have been given by Pandey et al (1984).

SAMIR data for Bhaskara II orbits in 1982 over the Arabian Sea are obtained from Space Applications Centre, Ahmedabad. For each grid the average brightness temperatures at 19.35 and $22.235 \mathrm{GHz}$ frequencies have been computed and then WV content $\left(\mathrm{gm} / \mathrm{cm}^{2}\right)$ and wind speed $(\mathrm{m} / \mathrm{sec})$ are estimated from the following regression equations given by Pandey et al (1984) and Pathak et al (1983).

$$
\begin{aligned}
& \mathrm{WV}=0.3178-8.9963 \mathrm{~F}, \\
& \mathrm{SW}=-14.43-0.1187 T_{B}(19)+0.1833 T_{B}(22),
\end{aligned}
$$


where $T_{B}(19)$ and $T_{B}(22)$ are the brightness temperatures at $19 \cdot 35$ and $22 \cdot 235 \mathrm{GHz}$ frequencies respectively and $F=\ln \left(280-T_{B}(22)\right)-\ln \left(280-T_{B}(19)\right)$.

\subsection{Relation between $W V$ content and surface dew point temperature}

In general, the moisture content in the atmosphere is more in the near surface layer and decreases with height. Smith (1966) originally developed the following general empirical relation between $\mathrm{WV}$ and surface dew point temperature $t_{d}\left({ }^{\circ} \mathrm{C}\right)$

$$
\mathrm{WV}=\frac{\varepsilon E_{0}}{g(\lambda+1)} \times 10^{\left(\alpha t_{t}-\beta\right) /\left(t_{1}+\gamma\right)}
$$

where $E_{0}=6108$ dynes $/ \mathrm{cm}^{2} ; \alpha=7.5 ; \beta=178.5^{\circ} \mathrm{C} ; \gamma=148.4^{\circ} \mathrm{C} ; \varepsilon=0.622$ and $\lambda$ is a power function which is dependent on both season and latitude. In order to simplify (4), $\left(t_{d}+\gamma\right)$ term is taken as $160 \cdot 2^{\circ} \mathrm{C}$ after considering normal $t_{d}$ value $\left(11.8^{\circ} \mathrm{C}\right)$ for the northern Indian Ocean. Minimum errors are expected if climatological $t_{d}$ is assigned since $t_{d}$ is one order less than $\gamma$. For the northern Indian Ocean region, $\lambda$ is taken from Smith's (1966) table. Finally (4) is simplified as following

$$
t_{d}=-0.3632+15 \cdot 0661 \ln (\mathrm{WV})
$$

In order to compare the r.m.s error in the estimation of $t_{d}$ from the above equation with that obtained from the actual data, a direct regression equation is also developed using the radiosonde data collected on board various research ships over two different parts of the northern Indian Ocean during MONSOON 77. Figure 1 shows the location of research ships along with the period of observations. The number of observations at each location is given in table 1 . A low correlation (correlation coefficient: 0.26 ; r.m.s error: $\pm 0.87^{\circ} \mathrm{C}$ ) is obtained between $t_{d}$ and In (WV), using all the data points as mentioned in table 1. This correlation is considerably improved (correlation coefficient: 0.94 ; r.m.s error: $\pm 0.24^{\circ} \mathrm{C}$ ) when

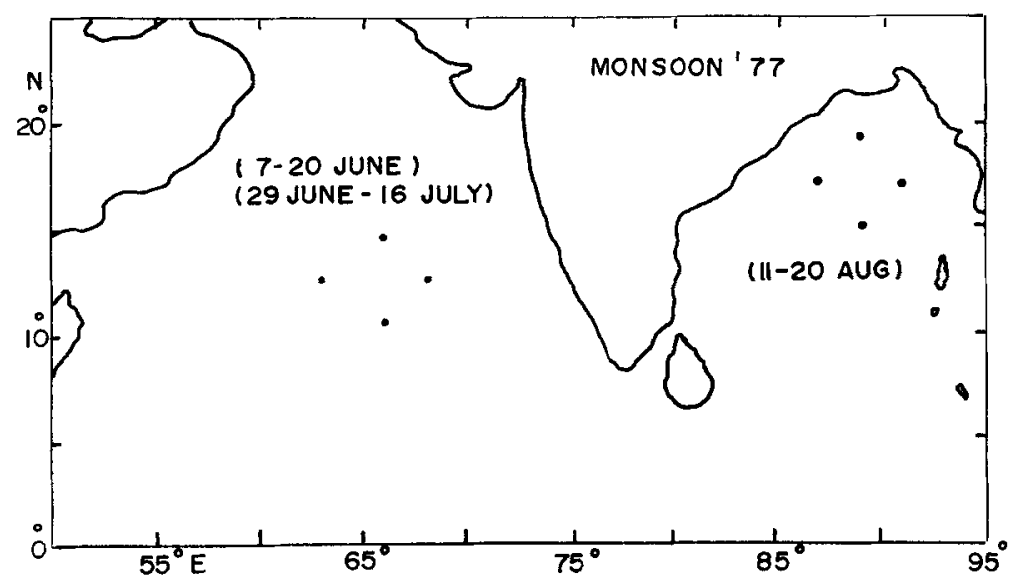

Figure 1. Location of the Research Ships along with the period of observations. 
Table 1. Number of radiosonde observations used for development of regression relation between dew point temperature and WV content.

\begin{tabular}{cccc}
\hline Location & June & July & $\begin{array}{c}\text { August } \\
1977\end{array}$ \\
\hline $10 \cdot 5^{\circ} \mathrm{N} \& 66 \cdot 0^{\circ} \mathrm{E}$ & 60 & 68 & - \\
$12 \cdot 5^{\circ} \mathrm{N} \& 63 \cdot 9^{\circ} \mathrm{E}$ & 52 & 68 & - \\
$12 \cdot 5^{\circ} \mathrm{N} \& 68 \cdot 0^{\circ} \mathrm{E}$ & 56 & 72 & - \\
$14 \cdot 5^{\circ} \mathrm{N} \& 66 \cdot 0^{\circ} \mathrm{E}$ & 44 & 72 & - \\
$15 \cdot 2^{\circ} \mathrm{N} \& 89 \cdot 0^{\circ} \mathrm{E}$ & - & - & 36 \\
$17 \cdot 2^{\circ} \mathrm{N} \& 91 \cdot 0^{\circ} \mathrm{E}$ & - & - & 32 \\
$17 \cdot 3^{\circ} \mathrm{N} \& 87 \cdot 0^{\circ} \mathrm{E}$ & - & - & 36 \\
$19 \cdot 3^{\circ} \mathrm{N} \& 89 \cdot 0^{\circ} \mathrm{E}$ & - & - & 40 \\
\hline
\end{tabular}

averaged monthly values at each location - total 12 points ( 4 ships $\times 3$ months)instead of individual values, are considered giving rise to the following equation:

$$
t_{d}=13.93+6.628 \ln (\mathrm{WV}) \text {. }
$$

It is to be pointed out here that even though daily $t_{d}$, WV values do not correlate well due to small-scale fluctuations, monthly averages agree better.

The scatter diagram of $\ln (\mathrm{WV})$ versus dew point temperatures and the regression lines obtained separately by (5) and (6) are shown in figure 2 . Equation (6) is finally used to estimate surface dew point temperatures from the SAMIR derived WV content since r.m.s. error $\left( \pm 0.92^{\circ} \mathrm{C}\right)$ obtained by (5) is high.

\section{Results and discussion}

To examine the validity of the empirical relation between WV content and $t_{d}$ over the northern Indian Ocean during the other seasons, the $t_{d}$ values estimated from SAMIR WV content during Bhaskara II orbits in 1982 are compared with ship's data (within $125 \mathrm{~km}$, since spatial resolution of SAMIR is $125 \mathrm{~km}$ ) (table 2). Dew point temperature estimates from SAMIR in general agree fairly well with the ship data when WV content is more than $4 \mathrm{gm} / \mathrm{cm}^{2}$. It is further seen that the SAMIR estimates of dew point temperatures are negatively biased (mean difference between satellite and ship data being $-1.27^{\circ} \mathrm{C}$ ) during January whereas they agree with ship's data during June (bias $0.12^{\circ} \mathrm{C}$ ). The seasonal variation in the $t_{d}$ bias may be due to two sources: (i) wind effect in SAMIR brightness temperatures $\left(T_{B}\right)$ and (ii) scale height effect in WV. Lower winds in January result in lower $T_{B}$ which leads to lower/underestimated WV $\left(t_{d}\right)$ values. Figure 3 shows that vertical distribution of WV content in January over the Arabian Sea (For example: Minicoy Island; Data source: Ramage and Raman 1972) is lesser exponential when compared to that in June. This lesser scale height effect gives rise to smaller WV for same $t_{d}$ and hence underestimates $t_{d}$ for a given $\mathrm{WV}$.

The satellite-derived SST over the Arabian Sea for June 1982, obtained from NOAA-GOSSTCOMP Charts are found to be negatively biased $\left(-1.4^{\circ} \mathrm{C}\right)$ with respect to ship SST data. This is comparable with the bias $\left(-0.9^{\circ} \mathrm{C}\right)$ obtained from 


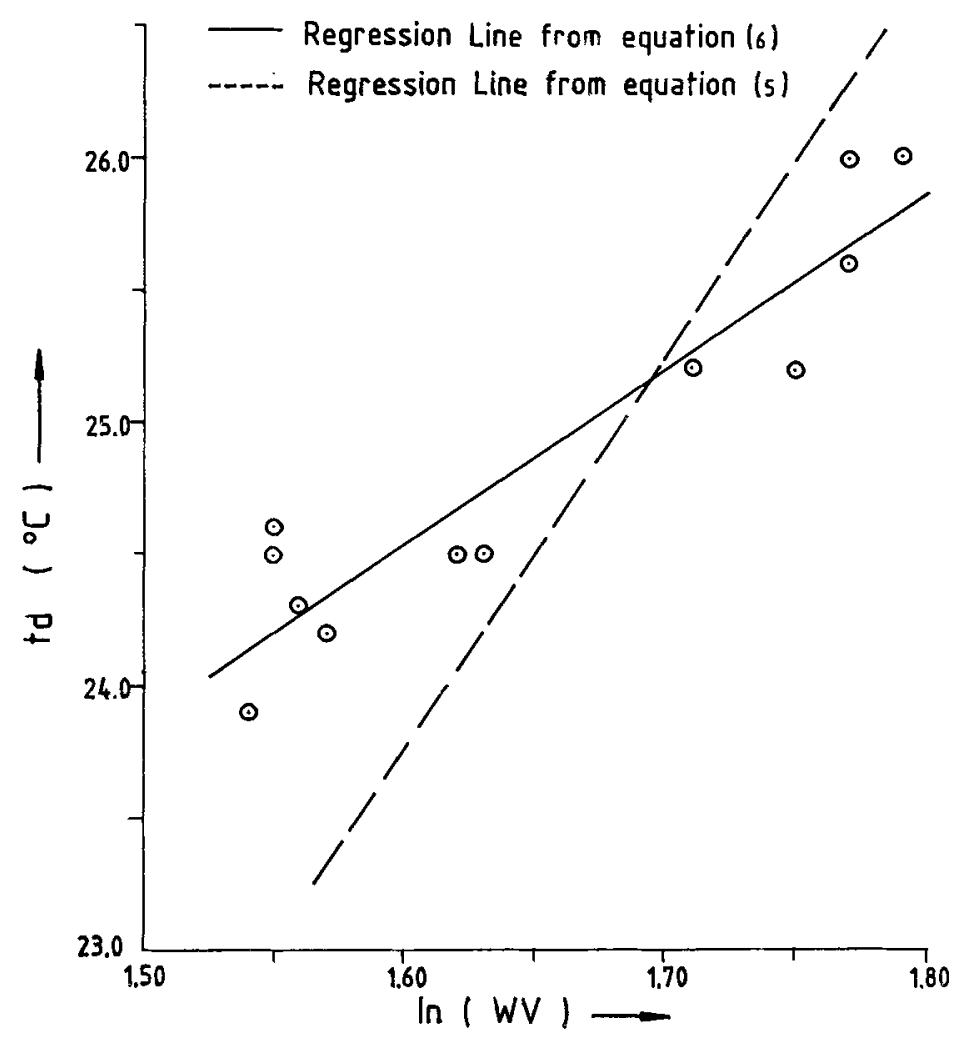

Figure 2. Scatter diagram of $\ln (\mathrm{WV})$ versus $t_{d}$ with regression lines.

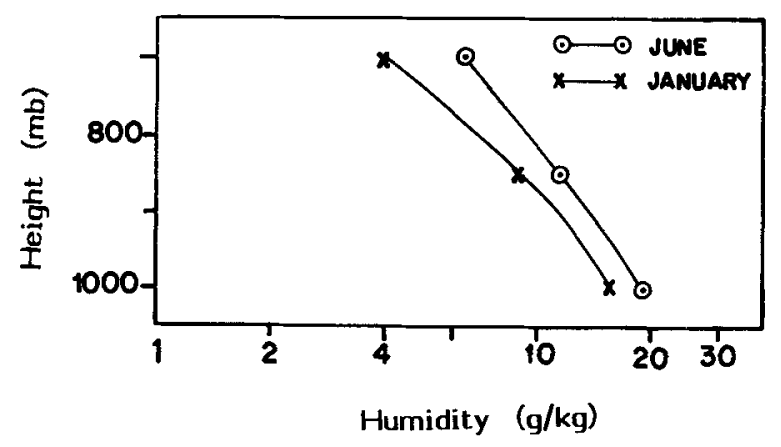

Figure 3. Vertical distribution of humidity at Minicoy Island in the Arabian Sea.

the study of Pathak (1982) for the north Indian Ocean. The negative bias, generally found more in warmer oceanic regions, is the result of the algorithms being presently used by NOAA which incorporate water vapour corrections on the basis of global climatological averages (Legeckis et al 1980). The winds derived from the SAMIR data for June agree well with ship data (bias: $-0.46 \mathrm{~m} / \mathrm{sec}$; r.m.s. 
Table 2. Comparison of dew point temperatures estimated from SAMIR data with the in situ ohservations.

\begin{tabular}{|c|c|c|c|c|c|c|c|}
\hline \multirow[b]{2}{*}{$\begin{array}{l}\text { Date } \\
\text { (1) }\end{array}$} & \multirow{2}{*}{$\begin{array}{l}\text { Orbit } \\
\text { No. } \\
(2)\end{array}$} & \multicolumn{2}{|c|}{$\begin{array}{c}\text { Time of (IST) } \\
\text { Observation }\end{array}$} & \multirow{2}{*}{$\begin{array}{l}\text { SAMIR } \\
\text { Position } \\
\text { (5) }\end{array}$} & \multirow{2}{*}{$\begin{array}{l}\text { WV content } \\
\left(\mathrm{g} / \mathrm{cm}^{2}\right) \\
\text { SAMIR } \\
(6)\end{array}$} & \multicolumn{2}{|c|}{$\begin{array}{c}\text { Dew point } \\
\left({ }^{\circ} \mathrm{C}\right)\end{array}$} \\
\hline & & $\begin{array}{l}\text { SAMIR } \\
\text { (3) }\end{array}$ & $\begin{array}{l}\text { Ship } \\
\text { (4) }\end{array}$ & & & $\begin{array}{l}\text { SAMIR } \\
(7)\end{array}$ & $\begin{array}{l}\text { Ship } \\
(8)\end{array}$ \\
\hline 13.1 .1982 & 821 & 1908 & 1730 & $\begin{array}{l}18^{\circ} 09 \mathrm{~N} \\
69^{\circ} 43 \mathrm{E}\end{array}$ & 2.06 & $15 \cdot 2$ & $17 \cdot 9$ \\
\hline 24.1 .1982 & 985 & 1517 & 1730 & $\begin{array}{l}09^{\circ} 10 \mathrm{~N} \\
72^{\circ} 57 \mathrm{E}\end{array}$ & $3 \cdot 30$ & $20 \cdot 1$ & $25 \cdot 0$ \\
\hline 28.1 .1982 & 1038 & 0242 & 0530 & $\begin{array}{l}19^{\circ} 41 \mathrm{~N} \\
85^{\circ} 57 \mathrm{E}\end{array}$ & $3 \cdot 56$ & $20 \cdot 8$ & $24 \cdot 0$ \\
\hline 29.1 .1982 & 1053 & 0227 & 2330 & $\begin{array}{l}10^{\circ} 11 \mathrm{~N} \\
75^{\circ} 43 \mathrm{E}\end{array}$ & $3 \cdot 76$ & $21 \cdot 4$ & $22 \cdot 0$ \\
\hline 24.2 .1982 & 1447 & 0351 & 0530 & $\begin{array}{l}16^{\circ} 11 \mathrm{~N} \\
62^{\circ} 12 \mathrm{E}\end{array}$ & $3 \cdot 87$ & $21 \cdot 7$ & $19 \cdot 7$ \\
\hline 19.3 .1982 & 1778 & 0734 & 0530 & $\begin{array}{l}11^{\circ} 28 \mathrm{~N} \\
74^{\circ} 29 \mathrm{E}\end{array}$ & $4 \cdot 14$ & $22 \cdot 4$ & $22 \cdot 0$ \\
\hline 20.3 .1982 & 1813 & 0728 & 0530 & $\begin{array}{l}13^{\circ} 42 \mathrm{~N} \\
73^{\circ} 50 \mathrm{E}\end{array}$ & $4 \cdot 30$ & $22 \cdot 8$ & $24 \cdot 0$ \\
\hline 22.3 .1982 & 1842 & 0523 & 0530 & $\begin{array}{l}06^{\circ} 33 \mathrm{~N} \\
87^{\circ} 48 \mathrm{E}\end{array}$ & $5 \cdot 96$ & $26 \cdot 1$ & $26 \cdot 5$ \\
\hline 30.3 .1982 & 1962 & 0338 & 0530 & $\begin{array}{l}13^{\circ} 05 \mathrm{~N} \\
74^{\circ} 01 \mathrm{E}\end{array}$ & $4 \cdot 59$ & $23 \cdot 4$ & 23.4 \\
\hline 07.4 .1982 & 2081 & 0013 & 2330 & $\begin{array}{l}08^{\circ} 58 \mathrm{~N} \\
76^{\circ} 16 \mathrm{E}\end{array}$ & 3.56 & $20 \cdot 8$ & $25: 1$ \\
\hline 19.4 .1982 & 2275 & 1940 & 1730 & $\begin{array}{l}09^{\circ} 19 \mathrm{~N} \\
70^{\circ} 52 \mathrm{E}\end{array}$ & $4 \cdot 70$ & $23 \cdot 7$ & 23.4 \\
\hline 23.4 .1982 & 2326 & 0508 & 0530 & $\begin{array}{l}16^{\circ} 32 \mathrm{~N} \\
67^{\circ} 34 \mathrm{E}\end{array}$ & $3 \cdot 63$ & $21 \cdot 0$ & $21 \cdot 8$ \\
\hline 26.4 .1982 & 2370 & 0252 & 0530 & $\begin{array}{l}15^{\circ} 22 \mathrm{~N} \\
85^{\circ} 53 \mathrm{E}\end{array}$ & $5 \cdot 40$ & $25 \cdot 3$ & $25 \cdot 0$ \\
\hline 04.5 .1982 & 2498 & 1301 & 1130 & $\begin{array}{l}05^{\circ} 07 \mathrm{~N} \\
82^{\circ} 27 \mathrm{E}\end{array}$ & $4 \cdot 37$ & $22 \cdot 8$ & $23-0$ \\
\hline 23.5 .1982 & 2788 & 1715 & 1730 & $\begin{array}{l}06^{\circ} 41 \mathrm{~N} \\
76^{\circ} 02 \mathrm{E}\end{array}$ & $6 \cdot 55$ & $27 \cdot 1$ & $26 \cdot 8$ \\
\hline 04.6 .1982 & 2961 & 0241 & 0530 & $\begin{array}{l}16^{\circ} 13 \mathrm{~N} \\
69^{\circ} 59 \mathrm{E}\end{array}$ & $4 \cdot 85$ & $24 \cdot 0$ & $23 \cdot 8$ \\
\hline 16.6 .1982 & 3154 & 2025 & 1730 & $\begin{array}{l}08^{\circ} 59 \mathrm{~N} \\
84^{\circ} 04 \mathrm{E}\end{array}$ & $6 \cdot 39$ & $26 \cdot 8$ & 26.9 \\
\hline 28.6 .1982 & 3265 & 0454 & 0530 & $\begin{array}{l}19^{\circ} 12 \mathrm{~N} \\
70^{\circ} 24 \mathrm{E}\end{array}$ & $5 \cdot 88$ & $26 \cdot 0$ & $26 \cdot 0$ \\
\hline
\end{tabular}

error: $\pm 0.94 \mathrm{~m} / \mathrm{sec}$ ). A scatter diagram between observed (ship data) and estimated (from SAMIR $T_{B}$ ) wind speeds is presented in figure 4.

The mean distribution of evaporation rates over the Arabian Sea for June 1982 estimated from Bhaskara II - SAMIR and NOAA-AVHRR data and from ship observations are presented in figures $5 \mathrm{a}, \mathrm{b}$ respectively. It is found that the spatial trends of evaporation rates derived from satellite data fairly agree with those obtained from ship observations. They are also comparable with climatological trends given by Hastenrath and Lamb (1979) (figure 5c). However there is a consistent underestimation of evaporation rates (shown by solid line contours in 


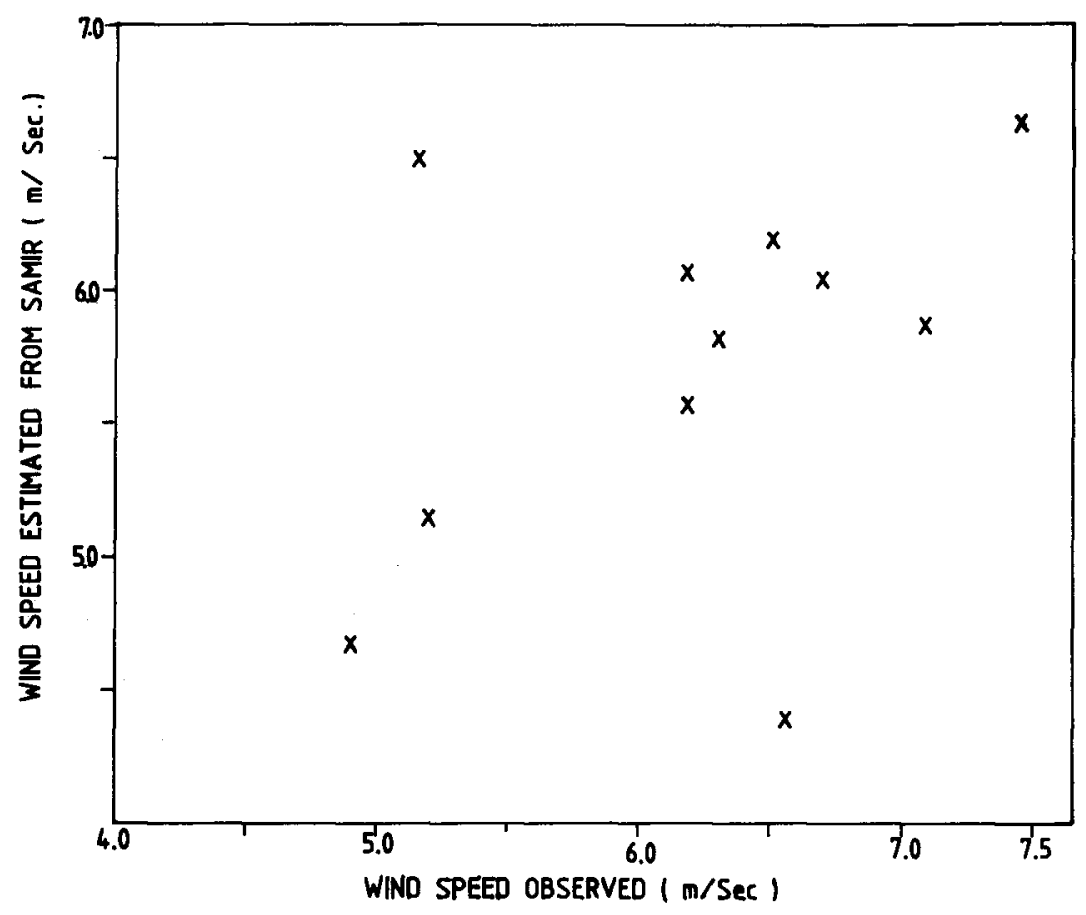

Figure 4. Scatter diagram of wind specds observed versus estimated.

figure 5a) from satellite observations which could be mainly due to the effect of negative bias of SST from AVHRR data as discussed earlier. When the bias $\left(-1.4^{\circ} \mathrm{C}\right)$ in SST from NOAA-AVHRR data set is removed, the accuracy in the evaporation rates improves to $\pm 0.8 \mathrm{~mm} /$ day (error $16 \%$ ). The dashed line contours in figure 5 a represent the evaporation rates after the removal of bias-correction in SST. This error estimate is based on monthly averages obtained in 11 four-degree grids where both satellite and ship observation coverages are reasonably good when compared to those in other grids in the area of study. Table 3 shows the number of data points considered in the averaging process for each grid. The present result is encouraging compared to the $30 \%$ error reported by Simon and Desai (1986) for the equatorial Indian Ocean based on GOES winds and TIROS temperature and humidity data. Further studies over the northern Indian Ocean are planned using variables derived from a single sensor (SMMR) to achieve evaporation estimations with better accuracy.

\section{Conclusions}

(i) An empirical equation between mean monthly WV content and the surface dew point temperature fields over the northern Indian Ocean is developed for the summer monsoon season with a correlation coefficient $(0.94)$ and r.m.s error of $\pm 0 \cdot 24^{\circ} \mathrm{C}$. 


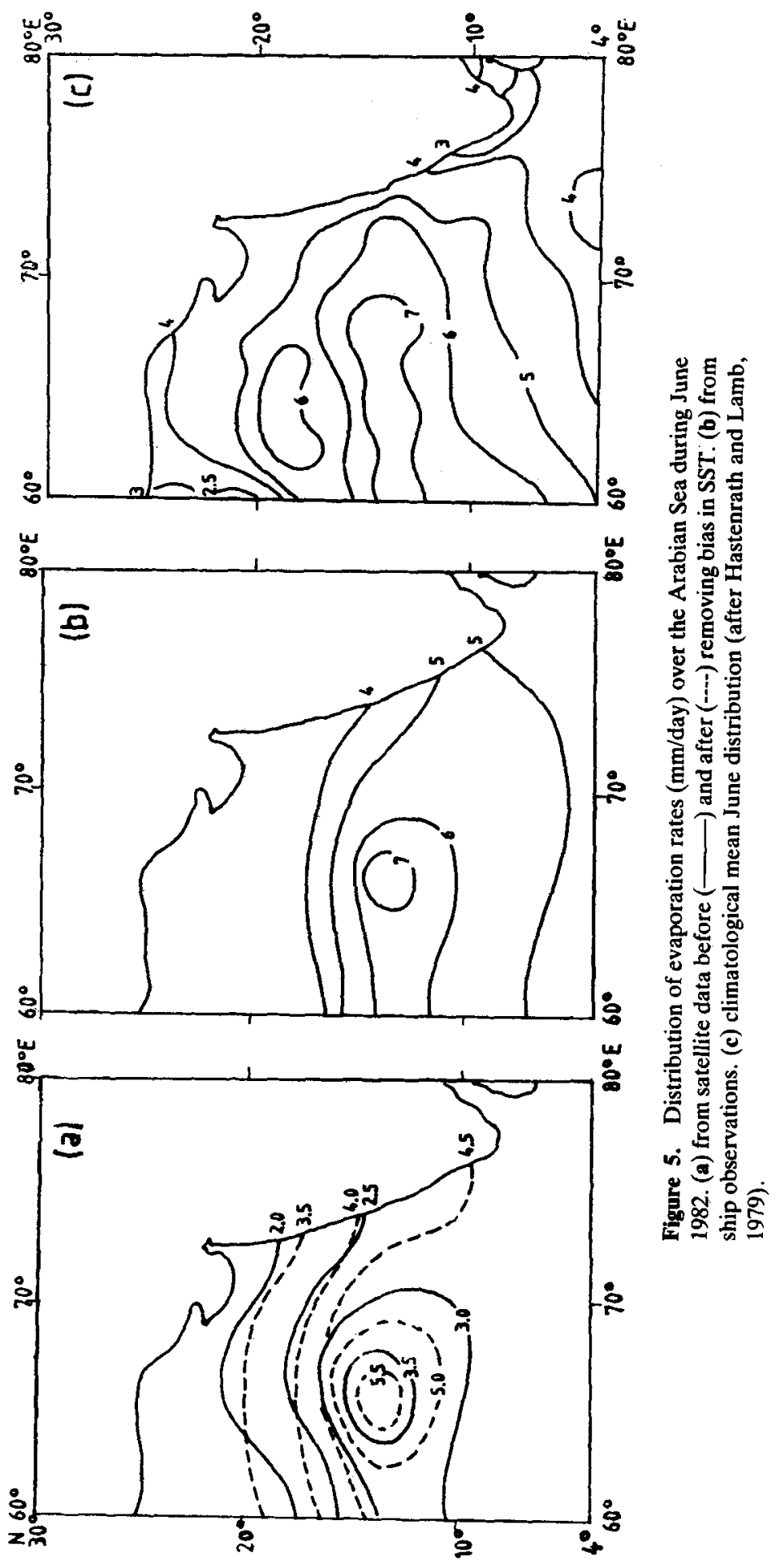


Table 3. Number of obervations used in the averaging process

\begin{tabular}{|c|c|c|c|}
\hline Grid No. & Area & Satellite & Ship \\
\hline 1. & $4-8^{\circ} \mathrm{N} ; 60-64^{\circ} \mathrm{E}$ & - & 2 \\
\hline 2. & $4-8^{\circ} \mathrm{N} ; 64-68^{\circ} \mathrm{E}$ & 1 & 1 \\
\hline 3. & $4-8^{\circ} \mathrm{N} ; 68-72^{\circ} \mathrm{E}$ & 3 & 1 \\
\hline 4. & $4-8^{\circ} \mathrm{N} ; 72-76^{\circ} \mathrm{E}$ & 30 & 11 \\
\hline 5. & $4-8^{\circ} \mathrm{N} ; 76-80^{\circ} \mathrm{E}$ & - & 25 \\
\hline 6. & $8-12^{\circ} \mathrm{N} ; 60-64^{\circ} \mathrm{E}$ & - & 9 \\
\hline 7. & $8-12^{\circ} \mathrm{N} ; 64-68^{\circ} \mathrm{E}$ & 3 & 8 \\
\hline 8. & $8-12^{\circ} \mathrm{N} ; 68^{8}-72^{\circ} \mathrm{E}$ & 20 & 20 \\
\hline 9. & $8-12^{\circ} \mathrm{N} ; 72-76^{\circ} \mathrm{E}$ & 23 & 23 \\
\hline 10. & $8-12^{\circ} \mathrm{N} ; 76-80^{\circ} \mathrm{E}$ & - & 10 \\
\hline 11. & $12-16^{\circ} \mathrm{N} ; 60-64^{\circ} \mathrm{E}$ & 4 & 3 \\
\hline 12. & $12-16^{\circ} \mathrm{N} ; 64-68^{\circ} \mathrm{E}$ & 16 & 5 \\
\hline 13. & $12-16^{\circ} \mathrm{N} ; 68-72^{\circ} \mathrm{E}$ & 32 & 10 \\
\hline 14. & $12-16^{\circ} \mathrm{N} ; 72-76^{\circ} \mathrm{E}$ & 24 & 30 \\
\hline 15. & $16-20^{\circ} \mathrm{N} ; 60-64^{\circ} \mathrm{E}$ & 18 & 5 \\
\hline 16. & $16-20^{\circ} \mathrm{N} ; 64-68^{\circ} \mathrm{E}$ & 29 & 12 \\
\hline 17. & $16-20^{\circ} \mathrm{N} ; 68-72^{\circ} \mathrm{E}$ & 39 & 16 \\
\hline 18. & $16-20^{\circ} \mathrm{N} ; 72-76^{\circ} \mathrm{E}$ & - & 6 \\
\hline 19. & $20-24^{\circ} \mathrm{N} ; 60-64^{\circ} \mathrm{E}$ & 11 & 3 \\
\hline 20. & $20-24^{\circ} \mathrm{N} ; 64-68^{\circ} \mathrm{E}$ & 22 & 7 \\
\hline 21. & $20-24^{\circ} \mathrm{N} ; 68-72^{\circ} \mathrm{E}$ & 4 & 3 \\
\hline
\end{tabular}

(ii) The evaporation rates can be estimated with a reasonable accuracy of $\pm 0.8 \mathrm{~mm} /$ day using different satellite data sets (SAMIR, AVHRR) when the bias in SST from NOAA-AVHRR data is removed.

\section{Acknowledgements}

The authors are thankful to $\mathrm{Dr} \mathrm{H} \mathrm{N}$ Siddiquie, Director, National Institute of Oceanography, Goa for his keen interest in this study. They are greatly indebted to Dr Y Sadhuram, Dr (Miss) S S Nath and Mr M R Ramesh Kumar of NIO and also to Drs Pranav S Desai and P N Pathak of Space Applications Centre, Ahmedabad, for their valuable suggestions in improving the manuscript. A fellowship from CSIR to MVR is gratefully acknowledged.

\section{References}

Babu V R, Rao M V and Sadhuram Y 1985 Trop. Ocean-Atmos. Newsl. 316 Bhumralker C M 1978 Indian J. Meteorol. Hydrol. Geophys. 29150

Bolsenga S J $1965 \mathrm{~J}$. Appl. Meteorol. 4430

Gadgil S, Joseph P V and Joshi N V 1984 Trop. Ocean-Atmos. Newsl. 277

Hastenrath S and Lamb P J 1979 Climatic Allas of the Indian Ocean, Part II : The Oceanic Heat Budget (Madison: University of Wisconsin Press)

Legeckis R, Legg E and Limeburner R 1980 Remote Sensing Environ. 9339

Liu W T 1984 Large-scale oceanic experiments and satellites (eds) C Gautier and M Fieux (Dordrecht: Reidel) p. 205 
Pandey P C, Gohil B S and Hariharan T A 1984 IEEE. Trans. Geosci. Remote Sensing GE22 647 Pathak P N 1982 Remote Sensing Environ. 12363

Pathak P N, Desai P S and Hariharan T A 1983 Indian J. Radio. Space Phys. 12141

Ramage C S and Raman C R V 1972 Meteorological Atlas of the International Indian Ocean Expedition (Washington DC: National Science Foundation) 2121 charts.

Rao G V, Schaub Jr W R and Puctz J 1981 Mon. Weather Rev. 109364

Reitan C H 1963 J. Appl. Meteorol. 2776

Shukla J 1975 J. Atmos. Sci. 32503

Shukla J and Mishra H M 1977 Mon. Weather Rev. 105998

Simon B and Desai P S 1986 Evaporation estimates over oceans from operational meteorological satellites: Case of equatorial Indian Ocean (paper presented at National Space Science Symposium, Gauhati, February 19-23, 1986)

Smith W D 1966 J. Appl. Meteorol. 5726

Taylors P K 1984 Large-scale oceanic experiments and satellites (eds) C Gautier and Fiuex (Dordrecht: Reidel) p. 223

Zillman J W $1972 A$ study of some aspects of the radiation and heat budgets of the southern hemisphere oceans (Canberra: Australian Government Publishing Service) Meteorological Study No. 26 Bureau of Meteorology, $562 p p$ 